Gut, 1968, 9, 99-105

\title{
Gastric secretory response to iron therapy
}

\author{
W. D. STONE 1 \\ From Dudley Road Hospital, Birmingham
}

Witts $(1953,1956)$ has postulated that iron deficiency may be a cause of gastritis and gastric secretory failure as well as of other epithelial changes, such as glossitis and pharyngitis. The return of gastric acidity after iron-deficiency anaemia had been cured was reported on several occasions at a time when test meals or small doses of histamine were used to evoke secretion (Chang, Yang, and Keefer, 1929; Burger and Witts, 1934; Davidson, 1933; Davidson and Fullerton, 1938; Hallén, 1938; Leonard, 1954; Badenoch, Evans, and Richards, 1957). The introduction of maximal histamine stimulation (Kay, 1953) showed that the older methods gave no accurate indication of the presence of achlorhydria, but workers using the augmented histamine test have also reported a return of acidity in similar circumstances, although still using Töpfer's reagent as a criterion (Davidson and Markson, 1955; Brumfitt, 1960). Accurate measurements of acid secretion have recently been made by Shearman, Delamore, and Gardner (1966) and by Jacobs, Lawrie, Entwistle, and Campbell (1966), and have shown that maximal acid output (M.A.O.) increased after iron therapy in a number of patients. Only one patient with true histamine-fast achlorhydria, however, was found to have recovered the ability to secrete acid.

The object of the present study was to compare the characteristics of patients in whom secretion improved with those in whom it did not, and to extend the observations to include changes in pepsin secretion and in the absorption of vitamin $B_{12}$.

\section{MATERIALS AND METHODS}

Maximal acid secretion was evoked by intravenous infusion of histamine (Lawrie, Smith, and Forrest, 1964). This test was chosen for two reasons. First, the output of acid obtained is higher than with the augmented histamine test, and many patients were expected to be hyposecretors. Secondly, in order to demonstrate a real change in secretion, it was important that the validity of each result was beyond doubt. It was felt to be impractical

'Present address: Department of Medicine, Queen Elizabeth Hospital, Birmingham, 15. to submit each patient to duplicate tests both before and after treatment, but the demonstration of a plateau of secretion with histamine infusion gave added confidence that collections of juice were complete.

Histamine acid phosphate was infused intravenously at $40 \mu \mathrm{g}$./kg./hour using a Palmer constant-infusion pump, and was preceded by $50 \mathrm{mg}$. of mepyramine maleate (Anthisan) also given intravenously. A double-lumen, wide-bore (18 Fr.) tube (Salem Co.) was used in all tests, and greatly aided the accurate collection of gastric juice (Williams and Benn, 1965). A plateau of secretion was reached in the fourth quarter-hour in nearly all cases, and the test was usually continued for two hours. Basal secretion was not studied. Acid was titrated to $p \mathrm{H} 7.0$ using $\mathrm{N} / 10 \mathrm{NaOH}$ and bromthymol blue as an indicator, and the maximum output was taken to be the output in the last hour of the test. Achlorhydria was said to be present when the $p \mathrm{H}$ did not fall below 7.0 measured with B.D.H. close-range paper (Bock, Richards, and Witts, 1963b).

Pepsin was estimated by the method of Hunt (1948) in each quarter-hour collection. If the volumes of juice were low an aliquot was taken from each collection and the peptic activity determined in the combined sample. Secretion of pepsin varied little while the infusion continued (Hirschowitz, London, and Pollard, 1957) and the output was calculated for the final hour of the test.

As it was intended to follow changes in serum $B_{12}$ levels, vitamin $B_{12}$ absorption was measured by the hepatic-uptake method (Glass, Goldbloom, Boyd, Laughton, Rosen, and Rich, 1956), which avoids giving a large dose of the vitamin and also obviates the collection of specimens by out-patients. The dose of ${ }^{58} \mathrm{Co}-\mathrm{B}_{12}$ was approximately $1 \mu \mathrm{c}$. and an exactly similar quantity was taken as a standard. Counting over the liver was carried out after seven days, and the standard was counted at a distance of $30 \mathrm{~cm}$. for the same period of time. Results were expressed in units, defined as the hepatic surface count divided by the standard count, which were independent of the exact administered dose and of the efficiency of the counter. As the results have not been compared with results after similar parenteral doses of $B_{12}$, they do not represent an exact measure of the quantity of $\mathrm{B}_{12}$ absorbed, but the present study was concerned with changes in absorption in individual patients. Carbachol, $0 \cdot 25 \mathrm{mg}$., was given subcutaneously with all tests (Mollin, Booth, and Baker, 1957). 
Gastric biopsies were taken with a Crosby-Kugler capsule at a distance of 45 to $55 \mathrm{~cm}$. from the incisor teeth. In this position over $80 \%$ of biopsies are of fundic mucosa (Joske, Finckh, and Wood, 1955). The histological appearances were described as normal, as superficial gastritis, or as atrophic gastritis (Bock, Arapakis, Witts, and Richards, 1963a).

Parietal-cell antibodies were sought in serum by the indirect immunofluorescent method of Bernhardt, Burkett, Fields, and Killian (1965). Results were expressed as negative or unequivocally positive, and a positive control serum was included on each occasion. Serum iron and iron-binding capacity were measured by the methods of Ramsay (1957a and b), and serum $B_{12}$ levels using Lactobacillus leichmanii (Matthews, 1962).

\section{REPRODUCIBILITY OF THE HISTAMINE-INFUSION TEST}

Two tests were performed within one week in each of eight subjects whose clinical state did not alter in that time (Table I). The M.A.O. differed by more than $2 \mathrm{mEq}$. only in one subject whose secretion was extremely high: this value has therefore been taken as a criterion of significant change. Pepsin secretion was less constant, presumably because it is not stimulated maximally by histamine (Hirschowitz, 1957; Gillespie and Bowen, 1962), and differences ranged from 0 to 6,698 units. No definite limit can therefore be set for assessing the significance of changes in pepsin secretion, and in this study they have been examined only in relation to changes in M.A.O.

TABLE I

RESULTS OF DUPLICATE HISTAMINE-INFUSION TESTS

\begin{tabular}{|c|c|c|c|c|}
\hline \multirow[t]{2}{*}{ Patient } & \multicolumn{2}{|c|}{ First Test } & \multicolumn{2}{|c|}{ Second Test } \\
\hline & $\begin{array}{l}\text { M.A.O. } \\
(m E q .)\end{array}$ & $\begin{array}{l}\text { Pepsin Output } \\
\text { (Hunt units) }\end{array}$ & $\begin{array}{l}\text { M.A.O. } \\
\text { (mEq.) }\end{array}$ & $\begin{array}{l}\text { Pepsin Output } \\
\text { (Hunt units) }\end{array}$ \\
\hline 1 & 0.0 & $\mathbf{0}$ & 0.0 & o \\
\hline 2 & $22 \cdot 2$ & 3,182 & $21 \cdot 3$ & 1,893 \\
\hline 3 & 40.1 & 5,131 & 38.2 & 8,177 \\
\hline 4 & $39 \cdot 3$ & 15,172 & $40 \cdot 8$ & 8,474 \\
\hline 5 & $21 \cdot 0$ & 5,785 & $22 \cdot 1$ & 7,564 \\
\hline 6 & 7.6 & 3,213 & 7.8 & 3,384 \\
\hline 7 & $75 \cdot 4$ & 12,549 & 67.2 & 12,207 \\
\hline 8 & $45 \cdot 4$ & 14,229 & $45 \cdot 2$ & 12,610 \\
\hline
\end{tabular}

\section{PATIENTS STUDIED}

Twenty-one patients suffering from iron-deficiency anaemia were investigated. They included 11 men and 10 women, aged 17 to 69 years (mean 42.3), with haemoglobin levels of between 4.9 and $11.3 \mathrm{~g} . / 100 \mathrm{ml}$. (mean 7.2). The serum iron levels lay between 10 and $67 \mu \mathrm{g} . / 100 \mathrm{ml}$. (mean 26), total iron-binding capacity between 171 and $641 \mu \mathrm{g} . / 100 \mathrm{ml}$. (mean 378), and the percentage saturation between 2.5 and 17.8 (mean 6.8).

In each patient efforts were made to uncover all possible aetiological factors, and especial attention was paid to the family history, menstrual pattern, and salicylate intake, while dietary histories were taken by a dietitian.
A rough estimate was made of the duration of the anaemia. Note was taken of the presence of glossitis and nail changes, and of any complaint of dysphagia. Investigations were carried out as indicated, but in all cases included repeated tests for faecal occult blood, and usually faecal fat and urinary d-xylose excretion.

When investigations were complete, patients were treated with parenteral and oral iron in large doses: in many cases an intravenous infusion of iron-dextran (Imferon) was given. The second investigation of gastric function was carried out after an interval of one and a half to 11 months (mean 5.7) at which time the haemoglobin levels lay between 10.5 and $16.8 \mathrm{~g} . / 100 \mathrm{ml}$. (mean 14.0). Serum iron levels were between 9 and $168 \mu \mathrm{g} . / 100 \mathrm{ml}$. (mean 79), total iron-binding capacity between 130 and $690 \mu \mathrm{g} . / 100 \mathrm{ml}$. (mean 348), and the percentage saturation between 1.3 and 82.2 (mean 28.9). In seven patients the serum iron level remained below $50 \mu \mathrm{g} . / 100 \mathrm{ml}$.

\section{RESULTS}

ACID SECRETION (FIG. 1) The M.A.O. in the anaemic patients was 0-29.8 $\mathrm{mEq}$./hour (mean 9.4), four patients being achlorhydric. After treatment it was 0-35.4 mEq./hour (mean 12.0).

Twelve patients showed no significant change, three being achlorhydric, six severe hyposecretors, and three normal.

On the other hand, eight patients showed increases of over $2 \mathrm{mEq}$., having originally secreted between 3.1 and $29.8 \mathrm{mEq}$. (mean $11 \cdot 5$ ). One other patient was at first achlorhydric, but after treatment produced an M.A.O. of $1.8 \mathrm{mEq}$.: this was also regarded as a significant change.

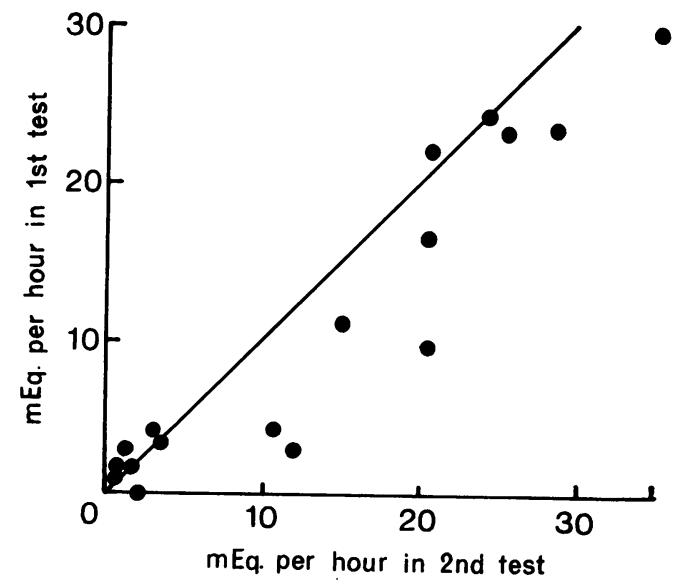

FIG. 1. Acid secretion before and after treatment. The diagonal line indicates no change in M.A.O. (Three achlorhydric patients are not included.) 
Those subjects who showed a significant rise in acid secretion will be referred to below as group 1, the remaining patients as group 2 .

PEPSIN SECRETION (FIG. 2) The output of the 21 patients before treatment was 0-8,293 Hunt units/ hour (mean 1,737) and after treatment was $0-13,420$ units (mean 3,485).

Twelve patients showed increases of from 31 to 5,429 units in the second test (mean 1,892), while in eight secretion fell by from 27 to 1,303 units (mean

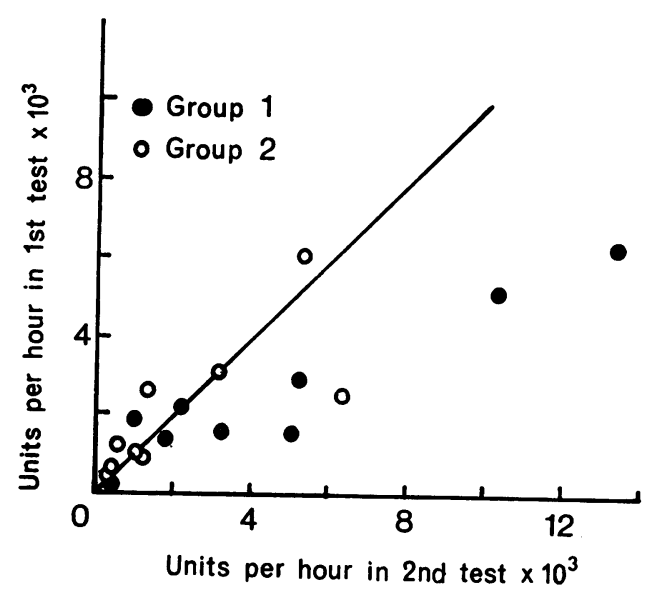

FIG. 2. Pepsin secretion before and after treatment. The diagonal line indicates no change in output.

Group 1 = patients whose M.A.O. increased.

Group 2 = patients whose M.A.O. did not increase.

(Three achlorhydric patients with absent or minimal pepsin secretion are not included.)

475). When groups 1 and 2 are considered separately, secretion altered by amounts varying from -908 to $+5,429$ units (mean $+1,934$ ) in group 1 and from $-1,303$ to $+3,815$ units (mean +108 ) in group 2 . Seven of the nine patients in group 1 showed increased outputs compared with five of 12 in group 2 and in only one of these five was the increase more than trifling. When changes in M.A.O. are plotted against changes in pepsin secretion (Fig. 3), there is a significant correlation between the two quantities.

VITAMIN B 12 ABSORPTION (FIG. 4) Nineteen patients were studied when anaemic, and only one gave a result below 0.17 units, the lower limit of normal in our laboratory: in her case absorption rose from 0.08 to 0.20 units when the test was repeated with intrinsic factor. Values found before treatment were $0.08-0.50$ units (mean 0.30 ), and in 17 patients

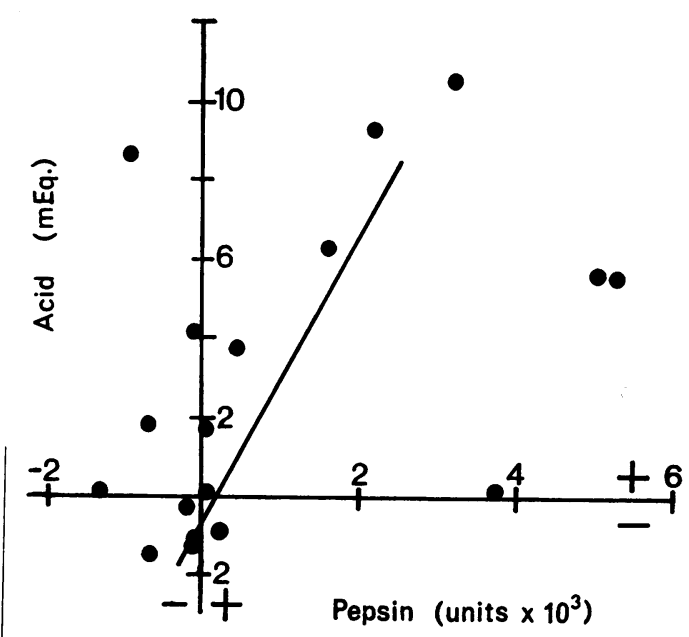

FIG. 3. The correlation of changes in pepsin output with changes in M.A.O.

$r=0.531 \quad$ S.E. $=0.224$

Change in pepsin output $=276.3$ (change in M.A.O.) $+178 \cdot 1$.

studied after treatment were 0.21 to 0.47 units (mean 0.36). Twelve patients showed an increased absorption on the second occasion and five a decrease. Five of the former were found in group 1 and seven in group 2.

SERUM $B_{12}$ LEVELS Levels of serum $B_{12}$ were normal (above $100 \mu \mu \mathrm{g} . / \mathrm{ml}$.) in all but one patient, who was

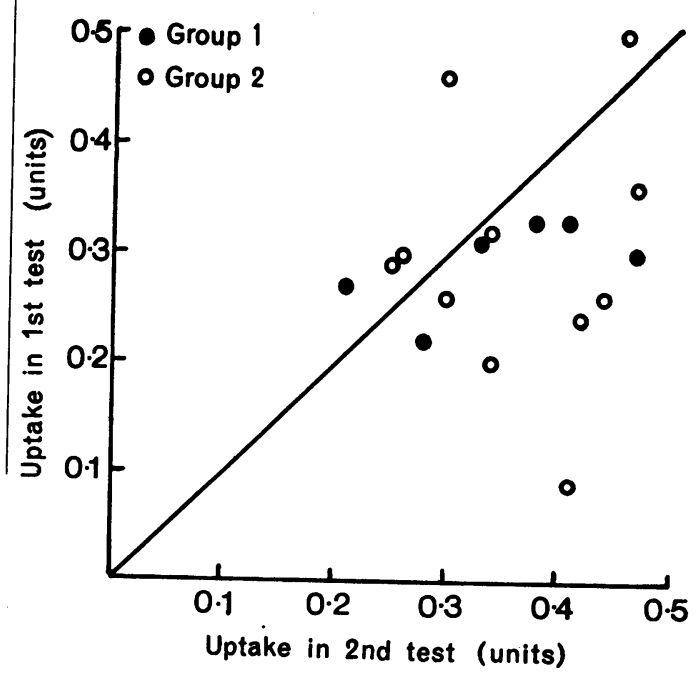

FIG. 4. $B_{12}$ absorption before and after treatment. The diagonal line indicates no change in absorption. 
achlorhydric, had parietal-cell antibodies, and gave a family history of pernicious anaemia, but whose $B_{12}$ absorption was normal. Her serum $B_{12}$ level was $93 \mu \mu \mathrm{g} . / \mathrm{ml}$. and had risen to $176 \mu \mu \mathrm{g} . / \mathrm{ml}$. at the time of the second study. The serum $B_{12}$ rose from 171 to $330 \mu \mu \mathrm{g} . / \mathrm{ml}$. in one other patient, who secreted $1.4 \mathrm{mEq}$./hour, and who also had parietalcell antibodies and a normal $B_{12}$ absorption. $B_{12}$ absorption increased in these two patients by 0.14 and 0.18 units respectively. In all other patients serum $B_{12}$ levels were above $200 \mu \mu \mathrm{g} . / \mathrm{ml}$. and did not change in any consistent way after treatment with iron.

\section{COMPARISON OF GROUPS 1 AND 2}

Groups 1 and 2 were analysed to see if reasons could be found for the difference between their responses. The sex distribution was similar but the average age of group 1 was 10 years less than that of group 2 (Table II). Treatment in both groups led

TABLE II

COMPOSITION OF THE TWO GROUPS WITH REGARD TO SEX, AGE, AND THE ADEQUACY OF TREATMENT

\begin{tabular}{|c|c|c|c|c|c|c|}
\hline \multirow{2}{*}{$\Lambda$} & \multirow[t]{2}{*}{ Men } & \multirow[t]{2}{*}{ Women } & \multirow{2}{*}{$\begin{array}{l}\text { Mean } \\
\text { Age } \\
\text { (years) }\end{array}$} & \multicolumn{3}{|c|}{ Mean Values after Treatment } \\
\hline & & & & $\begin{array}{l}\text { Haemoglobin } \\
(\mathrm{g} . / 100 \mathrm{ml} .)\end{array}$ & $\begin{array}{l}\text { Serum Iron } \\
(\mu \mathrm{g} .1100 \mathrm{ml} .)\end{array}$ & $\begin{array}{l}\text { Satura- } \\
\text { tion of } \\
\text { Iron- } \\
\text { binding } \\
\text { Capacity } \\
(\%)\end{array}$ \\
\hline Group 1 & 4 & 5 & $\begin{array}{l}36 \cdot 3 \\
(17-69)\end{array}$ & $\begin{array}{l}13 \cdot 1 \\
(10 \cdot 5-16 \cdot 8)\end{array}$ & $\begin{array}{l}102 \\
(38-167)\end{array}$ & $\begin{array}{l}34 \cdot 4 \\
(7 \cdot 7-69)\end{array}$ \\
\hline Group 2 & 7 & 5 & $\begin{array}{l}46 \cdot 8 \\
(29-67)\end{array}$ & $\begin{array}{l}14 \cdot 4 \\
(12 \cdot 4-17 \cdot 1)\end{array}$ & $\begin{array}{l}66 \\
(9-168)\end{array}$ & $\begin{array}{l}23 \cdot 9 \\
(1 \cdot 3-82)\end{array}$ \\
\hline
\end{tabular}

to satisfactory levels of haemoglobin (Fig. 5) and to a marked improvement in serum iron and in the saturation of iron-binding capacity. Both these latter values were, however, higher in group 1. Gastric function before treatment (Table III) was better preserved in group 1 , in which the mean secretion of both acid and pepsin was almost twice that in group 2. There was no difference in the initial values for $\mathrm{B}_{12}$ absorption.

Further analysis was undertaken with regard to the presence of gastritis and of parietal-cell antibodies, and to the aetiology of the anaemia (Table IV). There was a higher incidence of atrophic

TABLE III

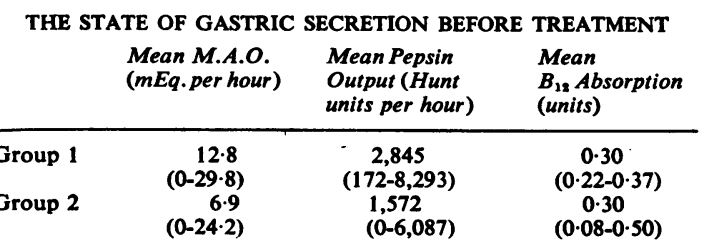

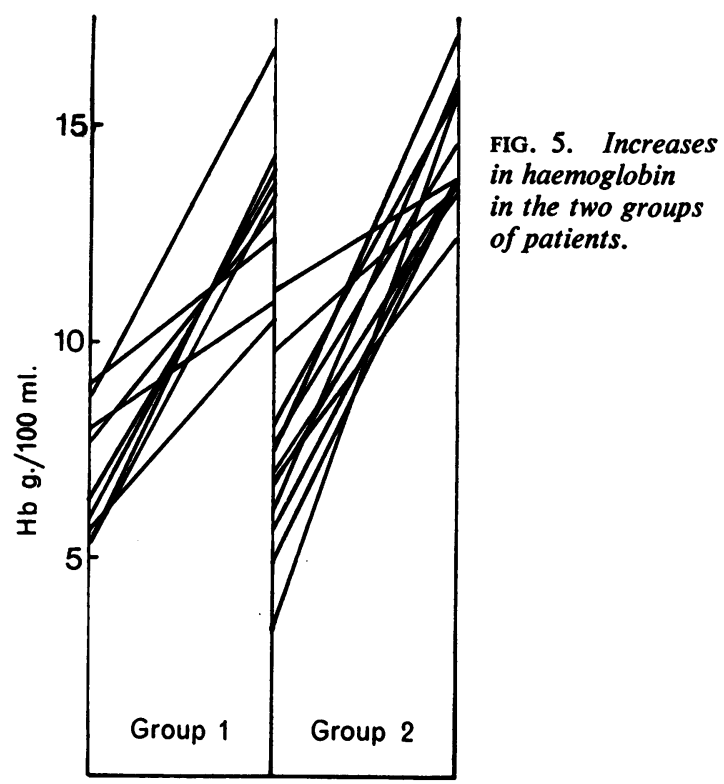

gastritis in group 2, but this histological pattern was found in some patients in both groups. Parietal-cell antibodies were found in only three patients, but these were all in group 2.

No cause was discovered for the anaemia (i.e., it was 'idiopathic') in six patients, whose mean M.A.O. was $9.9 \mathrm{mEq}$./hour before treatment: four of these were in group 1. Twenty-six contributory factors were discovered in the remaining 15 patients; in group 1 there were 1.6 factors for each patient, compared with 1.8 in group 2.

Estimates of the duration of anaemia can give only the most approximate indication of the truth, but the means of these estimates were 5.3 years in group 1 and 5.1 years in group 2, suggesting that there was no major difference. The frequency of changes and oropharyngeal symptoms was also the same in both groups.

\section{DISCUSSION}

Eight of the 21 patients in this series showed a significant rise in M.A.O. after the iron-deficiency anaemia had been treated, and one of the four achlorhydric patients recovered the ability to secrete acid. Similar findings have recently been reported by Shearman et al. (1966) who found increases of 0.3 to $11.1 \mathrm{mEq}$. in eight patients and $0.3 \mathrm{mEq}$. in one of nine achlorhydric patients, and by Jacobs et al. (1966) who describe.: Increases of $2 \mathrm{mEq}$. or more in 10 of their 33 patients.

Pepsin-secreting cells are thought to be more 
Gastric secretory response to iron therapy

TABLE IV

\begin{tabular}{|c|c|c|c|c|c|c|c|}
\hline \multicolumn{8}{|c|}{ AETIOLOGY, AUTOANTIBODIES, AND MUCOSAL HISTOLOGY } \\
\hline & \multirow{2}{*}{$\begin{array}{l}\text { No. of } \\
\text { Patients }\end{array}$} & \multicolumn{2}{|l|}{ Aetiology } & \multirow{2}{*}{$\begin{array}{l}\text { Patients with } \\
\text { Parietal-cell } \\
\text { Antibodies }\end{array}$} & \multicolumn{3}{|c|}{ Histology } \\
\hline & & $\begin{array}{l}\text { Patients with } \\
\text { No Identified } \\
\text { Cause }\end{array}$ & $\begin{array}{l}\text { No. of Identified } \\
\text { Aetiological } \\
\text { Factors }\end{array}$ & & Normal & $\begin{array}{l}\text { Superficial } \\
\text { Gastritis }\end{array}$ & $\begin{array}{l}\text { Atrophic } \\
\text { Gastritis }\end{array}$ \\
\hline $\begin{array}{l}\text { Group } 1 \\
\text { Group } 2\end{array}$ & $\begin{array}{r}9 \\
12\end{array}$ & $\begin{array}{l}4 \\
2\end{array}$ & $\begin{array}{r}8 \\
18\end{array}$ & $\begin{array}{l}\mathbf{0} \\
\mathbf{3}\end{array}$ & $\begin{array}{l}1 \\
1\end{array}$ & $\begin{array}{l}3 \\
4\end{array}$ & $\begin{array}{l}3 \\
6\end{array}$ \\
\hline
\end{tabular}

resistant to damage than are parietal cells (Glass, Speer, Nieburgs, Ishimori, Jones, Baker, Schwartz, and Smith, 1960; Bock et al., 1963a). In the present study pepsin secretion increased in most patients whose M.A.O. rose, and also in one-third of the remainder. The very low values found in two of the latter patients, however, may not have been estimated accurately as the acid concentration was less than $10 \mathrm{mEq}$./litre (Hunt, 1960). There was a significant correlation between the changes in acid and in pepsin secretion. Improvement in pepsin secretion has not previously been reported, and suggests that the gastric mucosa as a whole may be adversely affected by iron-deficiency anaemia.

Absorption of vitamin $B_{12}$ rose in 12 of 17 patients, but there was no correlation with the changes in acid and pepsin secretion. No consistent change in serum $B_{12}$ levels was found, but two patients in whom the level was initially below $200 \mu \mu \mathrm{g}$. $/ \mathrm{ml}$. showed substantial increases after treatment with iron, and in these patients at least the increases in $B_{12}$ absorption seem likely to represent a real improvement. Callender (1958) found no improvement in $\mathrm{B}_{12}$ absorption after iron therapy, but Cox, Meynell, Gaddie, and Cooke (1959) noticed that serum $B_{12}$ levels rose in a number of patients, and suggested that this was due to improved absorption. Williams, Jones, and Cox (1962) also reported that serum $B_{12}$ levels and $B_{12}$ absorption rose in patients with partial gastrectomies whose anaemia was treated with iron.

The fact that only one patient had a subnormal absorption of vitamin $\mathbf{B}_{12}$, although four were achlorhydric and eight had gross hyposecretion of acid and pepsin, may have been due to the routine use of carbachol. This drug was shown to increase $\mathrm{B}_{12}$ absorption by Mollin et al. (1957), although these results were not confirmed in a recent study (Dellipiani and Seaton, 1965) and it does not appear to stimulate the secretion of intrinsic factor (Ardeman and Chanarin, 1965). Stimulation of intestinal motility by carbachol, however, may have helped to compensate for a depressed secretion of intrinsic factor in some patients and changes in absorption may have been masked.

It appears that the secretion of the three main components of gastric juice is reversibly depressed in some patients with iron-deficiency anaemia, but as changes in acid secretion are most reliable, groups 1 and 2 were differentiated on this basis. Unfortunately it is not possible to draw any other clear distinctions between those who improved and those who did not. It is probably important that the former were on average younger, had larger outputs of acid and pepsin, and showed a lower incidence of atrophic gastritis. All three patients aged less than 20 fell into this group, although one of these was originally achlorhydric and one secreted only $4.4 \mathrm{mEq}$. Jacobs et al. (1966) found that improvement was much more common in those aged under 30 , and it is known that the incidence of hyposecretion and gastritis increases with advancing age (Vanzant, 1931; Faber, 1935). Any additional factor which depresses secretion would perhaps be more likely to have an irreversible effect in a patient whose gastric mucosa was already severely damaged. However, patients with similar ages and similar levels of secretion were found in both groups.

It might be that the differences in response were due to differences in the effectiveness of treatment. The mean serum iron level and the saturation of iron-binding capacity were less in group 2 after treatment, and seven of these 12 patients then had a saturation of less than $16 \%$, a convenient level for indicating iron-deficiency (Bainton and Finch,1964). However, two patients in group 1 also had saturations below this level. All patients had received large amounts of parenteral iron, and the haemoglobin levels in group 2 were all above $12.4 \mathrm{~g} . / 100$ ml. (Fig. 5), the mean level actually being higher than in group 1. It is possible, however, that more patients would have responded if the serum iron had reached the normal range in all those who were studied.

The three patients with parietal-cell antibodies showed no increases in acid and pepsin secretion, but this may have been solely because the mucosal lesions were very severe: two were achlorhydric and one secreted $3.3 \mathrm{mEq}$, while all had atrophic gastritis. In other respects the results of this study give no support to the theory of Delamore and Shearman (1965) that gastritis is secondary to iron 
deficiency only in patients in whom there are obvious causes for anaemia, such as chronic haemorrhage. They proposed that in patients with 'idiopathic' anaemia gastritis and achlorhydria were usually primary, often associated with autoantibodies and led to malabsorption of iron. If achlorhydria is the only demonstrable cause of iron deficiency, however, the mucosal lesion must inevitably be very severe and therefore less likely to respond to iron therapy. In this study there were more patients whose anaemia was classed as 'idiopathic' among those who responded to treatment, and equal numbers of identifiable aetiological factors among the remaining patients in both groups. It is common to find several such factors in one patient, and this implies that patients with 'idiopathic' anaemia are probably those in whom a number of minor factors summate (Beveridge, Bannerman, Evanson, and Witts, 1965). The inaccuracies of dietary and menstrual histories and of tests for faecal occult blood are well known.

There is evidence that antibodies to parietal cells are most common among patients with severe gastritis and marked hyposecretion (Dagg, Goldberg, Anderson, Beck, and Gray, 1964; Coghill, Doniach, Roitt, Mollin, and Williams, 1965; Wright, Whitehead, Wangel, Salem, and Schiller, 1966). Although they are very common in frank and latent pernicious anaemia (Wright et al., 1966) there is no proof that these antibodies cause gastritis, and it is possible that they are produced as a reaction to mucosal damage, the result of iron deficiency (Markson and Moore, 1962; Moulton, 1964) or of other factors (Edwards and Coghill, 1966). MacFadyen, Goldberg, Dagg, and Anderson (1965) found a significant history of bleeding only among those iron-deficient patients with both achlorhydria and antibodies who did not have relatives with antibodies. The equally low incidence of parietal-cell antibodies in patients who had had partial gastrectomy for duodenal ulcer and in others with gastric carcinoma has also suggested that antibodies may be a reaction to gastritis, but that few patients are able to produce them (Kravetz, van Noorden, and Spiro, 1967).

Evidence linking atrophic gastritis with Hashimoto's thyroiditis (Irvine, Davies, Delamore, and Williams, 1962; Mackay, 1964) provides the strongest support for the idea that parietal cell antibodies play an aetiological role in some patients. The large number of other factors which have also been implicated, however (Edwards and Coghill, 1966), makes it probable that the disease has more than one cause in most patients, and iron deficiency may be one of these, having an effect on function which may reflect or lead to structural damage. If this damage can stimulate the formation of autoantibodies, or ead to a perpetuation of iron deficiency through a diminished absorption of iron (Jacobs, Bothwell, and Charlton, 1964), a vicious circle may be set up which probably represents the true state of affairs in most patients. Once damage has progressed to a certain stage, recovery due to iron therapy is unlikely.

The deduction from these findings must be that iron deficiency of all grades must be sought and treated effectively before permanent changes develop, and that patients in whom it is likely to recur should be followed with regular blood examinations. Early and effective treatment might lessen the incidence of gastritis, and eventually even that of gastric carcinoma.

\section{SUMMARY}

Nine out of 21 patients showed an increase in acid secretion after treatment of iron-deficiency anaemia. Improvement in pepsin secretion and vitamin $\mathbf{B}_{12}$ absorption was also seen in a number of patients. Such changes appeared to be more common in young people, whose secretion was originally less impaired, and who had less severe gastritis. No evidence was found to suggest that patients with 'idiopathic' anaemia differed in this respect from those in whom the cause was more obvious. The significance of these findings is discussed.

My thanks are due to the members of the medical staff at Dudley Road Hospital, and especially to Dr. A. Paton, for allowing me to study their patients. Mr. W. B. Yeoman kindly provided facilities for me to perform the pepsin estimations, Mr. B. A. Goddard devised the method of expressing $B_{12}$ absorption and Dr. $H$. Thompson supervised the histological assessment. Mr. R. J. Leeming carried out the immunofluorescent tests and Miss F. Wakeford gave great help by taking the dietary histories. Mr. J. A. Williams stimulated my interest in this subject, and Dr. W. T. Cooke gave much helpful criticism.

\section{REFERENCES}

Ardeman, S., and Chanarin, I. (1965). Stimulation of gastric intrinsic factor secretion. Brit. med. J., 1, 1417-1418.

Badenoch, J., Evans, J. R., and Richards, W. C. D. (1957). The stomach in hypochromic anaemia. Brit. J. Haemat., 3, 175-185.

Bainton, D. F., and Finch, C. A. (1964). The diagnosis of irondeficiency anemia. Amer. J. Med., 37, 62-70.

Bernhardt, H., Burkett, L. L., Fields, M. L., and Killian, J. (1965). The diagnostic significance of the parietal cell immunofluorescent test. Ann. intern. Med., 63, 635-641.

Beveridge, B. R., Bannerman, R. M., Evanson, J. M., and Witts, L. J. (1965). Hypochromic anaemia. A retrospective study and follow-up of 378 in-patients. Quart. J. Med., 34, 145-161.

Bock, O. A. A., Arapakis, G., Witts, L. J., and Richards, W. C. D. (1963a). The serum pepsinogen level with special reference to the histology of the gastric mucosa. Gut, 4, 106-111.

-, Richards, W. C. D., and Witts, L. J. (1963b). The relationship between acid secretion after augmented histamine stimulation and the histology of the gastric mucosa. Ibid., 4, 112-114.

Brumfitt, W. (1960). Primary iron-deficiency anaemia in young men. Quart. J. Med., 29, 1-18. 
Burger, G. N., and Witts, L. J. (1934). Hypochromic anaemia in men. Guy's Hosp. Rep., 84, 14-24.

Callender, S. T., in discussion of Taylor, K. B., and Witts, L. J. (1958). Effects of chronic iron deficiency in the rat. Quart. J. Med., 27, 565-566.

Chang, H. C., Yang, C. S., and Keefer, C. S. (1929). Improvement in gastric function in patients following recovery from secondary anaemia. Nat. med. J. China, 15, 752-763.

Coghill, N. F., Doniach, D., Roitt, I. M., Mollin, D. L., and Williams, A. W. (1965). Autoantibodies in simple atrophic gastritis. Gut, 6, 48-56.

Cox, E. V., Meynell, M. J., Gaddie, R., and Cooke, W. T. (1959) Inter-relation of vitamin $B_{12}$ and iron. Lancet, 2, 998-1001.

Dagg, J. H., Goldberg, A., Anderson, J. R., Beck, J. S., and Gray, K. G. (1964). Autoimmunity in iron-deficiency anaemia. Brit. med. J., 1, 1349-1350.

Davidson, L. S. P. (1933). Pernicious anaemia with return of hydrochloric acid and ferments after treatment. Ibid., 1, 182-183.

-, and Fullerton, H. W. (1938). Chronic nutritional hypochromic anaemia. Edinb. med. J., 45, Pt. I 1-23, Pt. II 102-131, Pt. III 193-212.

Davidson, W. M. B., and Markson, J. L. (1955). The gastric mucosa in iron-deficiency anaemia. Lancet, 2, 639-643.

Delamore, I. W., and Shearman, D. J. C. (1965). Chronic irondeficiency anaemia and atrophic gastritis. Ibid., 1, 889-891.

Dellipiani, A. W., and Seaton, D. A. (1965). Carbachol and vitamin $B_{12}$ absorption. Brit. med. J., 1, 1230-1231.

Edwards, F. C., and Coghill, N. F. (1966). Aetiological factors in chronic atrophic gastritis. Ibid., 2, 1409-1415.

Faber, K. (1935). Gastritis and Its Consequences. Oxford University Press, London (ptd. Copenhagen).

Gillespie, I. E., and Bowen, D. J. (1962). The gastric secretion of pepsin in man. Gut, 3, 255-259.

Glass, G. B. J., Goldbloom, A. A., Boyd, L. J., Laughton, R. Rosen, S., and Rich, M. (1956). Intestinal absorption and hepatic uptake of radioactive vitamin $B_{12}$ in various age groups and the effect of intrinsic factor preparations. Amer. J. clin. Nutr., 4, 124-133.

—, Speer, F. D., Nieburgs, H. E., Ishimori, A., Jones, E. L., Baker, H., Schwartz, S. A., and Smith, R. (1960). Gastric atrophy, atrophic gastritis, and gastric secretory failure. Gastroenterology, 39, 429-453.

Hallén, L. (1938). Iron and epithelium. Some clinical observations. 2. Gastric secretion. Acta med. scand., suppl. 90, 398-405.

Hirschowitz, B. I. (1957). Pepsinogen: its origins, secretion and excretion, Physiol. Rev., 37, 475-511.

—, London, J. L., and Pollard, H. M. (1957). Histamine stimulation of gastric pepsin secretion in man. Gastroenterology, 32, 85-87.

Hunt, J. N. (1948). A method for estimating peptic activity in gastric contents. Biochem. J., 42, 104-109.

- (1960). Personal communication. Quoted by Gillespie, I. E., and Bowen, D. J. (1962).

Irvine, W. J., Davies, S. H., Delamore, I. W., and Williams, A. W. (1962). Immunological relationship between pernicious anaemia and thyroid disease. Brit. med. J., 2, 454-456.
Jacobs, A., Lawrie, J. H., Entwistle, C. C., and Campbell, H. (1966) Gastric acid secretion in chronic iron-deficiency anaemia. Lancet, 2, 190-192.

Jacobs, P., Bothwell, T., and Charlton, R. W. (1964). Role of hydrochloric acid in iron absorption. J. appl. Physiol., 19, 187-188.

Joske, R. A., Finckh, E. S., and Wood, I. J. (1955). Gastric biopsy: a study of 1,000 consecutive successful gastric biopsies. Quart. J. Med., 24, 269-294.

Kay, A. W. (1953). Effect of large doses of histamine on gastric secretion of $\mathrm{HCl}$. An augmented histamine test. Brit. med. J., 2, 77-80.

Kravetz, R. E., van Noorden, S., and Spiro, H. M. (1967). Parietalcell antibodies in patients with duodenal ulcer and gastric cancer. Lancet, 1, 235-237.

Lawrie, J. H., Smith, G. M. R., and Forrest, A. P. M. (1964). The histamine-infusion test. Ibid., 2, 270-273.

Leonard, B. J. (1954). Hypochromic anaemia in R.A.F. recruits. Ibid., 1, 899-902.

MacFadyen, I. J., Goldberg, A., Dagg, J. H., and Anderson, J. R. (1965). Incidence of gastric parietal cell antibody in families of patients with iron deficiency anaemia. (Abstract). Scot. med. J., 10, 490.

Mackay, I. R. (1964). Autoimmune serological studies in chronic gastritis and pernicious anaemia. Gut., 5, 23-26.

Markson, J. L., and Moore, J. M. (1962). Autoimmunity in pernicious anaemia and iron-deficiency anaemia: a complement-fixation test using human gastric mucosa. Lancet., 2, 1240-1243.

Matthews, D. M. (1962). Observations on the estimation of serum vitamin $\mathbf{B}_{18}$ using Lactobacillus leichmannii. Clin. Sci., 22, 101-111.

Mollin, D. L., Booth, C. C., and Baker, S. J. (1957). The absorption of vitamin $B_{13}$ in control subjects, in Addisonian pernicious anaemia and in the malabsorption syndrome. Brit. J. Haemat., $3,412-428$.

Moulton, B. (1964). Autoimmunity in iron-deficiency anaemia. Brit. med. J., 2, 189.

Ramsay, W. N. M. (1957a). The determination of iron in blood plasma or serum. Clin. chim. Acta, 2, 214-220.

- (1957b). The determination of the total iron-binding capacity of serum. Ibid., 2, 221-226.

Shearman, D. J. C., Delamore, I. W., and Gardner, D. L. (1966). Gastric function and structure in iron deficiency. Lancet, 1, 845-848.

Vanzant, F. R. (1931). The normal range of gastric acidity from youth to old age: an analysis of 3,746 records. Proc. Mayo Clin., 6, 297-300.

Williams, J. A., Jones, C. T., and Cox, E. V. (1962). The effect of iron therapy on serum vitamin $B_{12}$ levels after gastrectomy. (Abstract). Brit. J. Surg., 50, 95.

-, and Benn, A. (1965). A gastric sampling-tube. Lancet, 1, 1309.

Witts, L. J. (1953). Haemopoiesis in relation to disorders of the alimentary tract. Gastroenterologia (Basel), 79, 322-327.

(1956). Anaemia and the Alimentary Tract. Royal College of Physicians, Edinburgh.

Wright, R., Whitehead, R., Wangel, A. G., Salem, S. N., and Schiller, K. F. R. (1966). Autoantibodies and microscopic appearance of gastric mucosa. Lancet, 1, 618-621. 